\title{
Changes by use and management in alluvial plain soils in southern Brazil
}

\author{
Alterações por uso e manejo em solos de planície aluvial no sul do Brasil \\ Cambios por uso y manejo en suelos de llanuras aluviales en el sur de Brasil
}

Received: 11/15/2021 | Reviewed: 11/24/2021 | Accept: 11/25/2021| Published: 12/07/2021

Edsleine Ribeiro

ORCID: https://orcid.org/0000-0002-1184-9195

Universidade Federal do Rio Grande do Sul, Brazil

E-mail: edsleine@ hotmail.com

Priscila Vogelei Ramos

ORCID: https://orcid.org/0000-0002-6232-3441

Universidad de Burgos, Espanha

E-mail: priscilav.ramos@yahoo.com.br

Tatiele Fruett

ORCID: https://orcid.org/0000-0003-2678-6374 Universidade Federal do Rio Grande do Sul, Brazil

E-mail: tatielefruett@yahoo.com.br

Paulo César do Nascimento

ORCID: https://orcid.org/0000-0003-1079-3748 Universidade Federal do Rio Grande do Sul, Brazil

E-mail: pcnasc@ufrgs.br

Estéfane Chaves

ORCID: https://orcid.org/0000-0001-9102-1429 Universidade Federal do Rio Grande do Sul, Brazil

E-mail: ecagronomia@gmail.com

\begin{abstract}
Agricultural land use causes changes in physical and chemical attributes of the soil, due to the management practices employed the productive capacity of the soil can be compromised under different agricultural systems. The soils of Porto Alegre are quite diverse reflecting the geology, topography and drainage network of the region, and include lowland soils, like the alluvial plain of the Arroio Dilúvio. This study was carried out in four landscape units (Native Forest, Agroforestry System, Horse Farm and Agricultural Crops), to assess changes in soil characteristics after different types of land use and management on the plain of the Dilúvio Arroio. We sampled disturbed and undisturbed soil samples for chemical $\left(\mathrm{pH}, \mathrm{EC}, \mathrm{V}, \mathrm{SOM}, \mathrm{CEC}, \mathrm{Al}^{3+}, \mathrm{H}+\mathrm{Al}\right)$ and physical analysis (porosity, microporosity and macroporosity). These chemical and physical attributes of the soils, especially $\mathrm{pH}, \mathrm{V} \%$, SOM, CEC and $\mathrm{Al}^{3+}$, underwent changes under the different types of land use and management, with significant differences. Most changes were detected in the cropland soils. Multivariate analysis demonstrated the influence of the different types of land use, at the surface, land use and management had the greatest influence, while at depth, the proximity of the areas was the predominant factor.
\end{abstract}

Keywords: Land use; Attributes of the soil; Soil quality.

\section{Resumo}

$\mathrm{O}$ uso do solo agrícola provoca alterações nos atributos físicos e químicos do solo, devido às práticas de manejo empregadas a capacidade produtiva do solo pode ser comprometida sob diferentes sistemas agrícolas. O município de Porto Alegre apresenta diversidade de solos, topografia e redes de drenagem superficial, em meio a esta diversidade de ambientes é possível encontrar áreas de baixada como a planície aluvial do Arroio Dilúvio. Este estudo foi realizado em quatro unidades de paisagem (Mata, Sistema Agroflorestal, Potreiro, Plantas de Lavoura) com o objetivo de avaliar mudanças nas características dos solos após diferentes usos e manejos, na planície do Arroio Diluvio, em Porto Alegre. Para o estudo foram realizadas coletas de amostras deformadas e indeformadas de solo, em profundidades de 0-20 $\mathrm{cm}$ e $60-80 \mathrm{~cm}$, para análises químicas $\left(\mathrm{pH}, \mathrm{CE}, \mathrm{V}, \mathrm{MOS}, \mathrm{CTC}, \mathrm{Al}^{3+}, \mathrm{H}+\mathrm{Al}\right)$ e físicas (porosidade, microporosidade e macroporosidade). Os atributos químicos e físicos dos solos sofreram alterações nos diferentes usos e manejos, destacando-se o $\mathrm{pH}, \mathrm{V} \%, \mathrm{MOS}, \mathrm{CTC}_{\mathrm{e}} \mathrm{Al}^{3+}$, com diferenças significativas. $\mathrm{O}$ solo da área cultivada com plantas de lavoura foi o solo que apresentou mais alterações. A análise multivariada evidenciou as influências para as diferenças entre os tipos de uso do solo, pois em superfície o uso e manejo se mostrou o fator de maior influência, enquanto em profundidade, a proximidade das áreas foi o fator predominante.

Palavras-chave: Uso da terra; Atributos dos solos; Qualidade do solo. 


\section{Resumen}

El uso de suelos agrícolas provoca cambios en los atributos físicos y químicos del suelo, debido a las prácticas de manejo empleadas la capacidad productiva del suelo puede verse comprometida bajo diferentes sistemas agrícolas. El municipio de Porto Alegre cuenta con diversidad de suelos, topografía y redes de drenaje superficial, en medio de esta diversidad de ambientes es posible encontrar zonas de tierras bajas como la llanura aluvial del Arroio Dilúvio. Este estudio se realizó en cuatro unidades de paisaje (Bosque, Sistema Agroforestal, Potrero, Plantas de Cultivo) con el objetivo de evaluar cambios en las características del suelo después de diferentes usos y manejos, en la llanura Arroio Diluvio, en Porto Alegre. Para el estudio, se recolectaron muestras de suelo deformado y no perturbado a profundidades de 0-20 cm y 60-80 cm, para análisis químicas $\left(\mathrm{pH}, \mathrm{CE}, \mathrm{V}, \mathrm{MOS}, \mathrm{CTC} \mathrm{Al}^{3+}, \mathrm{H}+\mathrm{Al}\right)$ y físicos (porosidad, microporosidad y macroporosidad). Los atributos químicos y físicos de los suelos sufrieron cambios en los diferentes usos y manejos, destacando el $\mathrm{pH}$, V\%, MOS, CTC y Al ${ }^{3+}$, con diferencias significativas. El suelo de la zona cultivada con plantas de cultivo fue el suelo que presentó más alteraciones. El análisis multivariado evidenció las influencias para las diferencias entre los tipos de uso del suelo, ya que en superficie el uso y manejo fue el factor más influyente, mientras que en profundidad, la proximidad de las áreas fue el factor predominante.

Palabras clave: Uso de la tierra; Atributos del suelo; Calidad del suelo.

\section{Introduction}

Unlike air or water quality concepts, there are no unique standards or normatization to assess soil quality, currently various concepts to define soil quality or degradation are considered (Araujo et al., 2012). Nevertheless, most definitions empahsize the need to adopt a series of properties, especially the context of land use and land cover. Soil quality indicators are measurable properties (quantitative or qualitative) of the soil or plant involved in a process or activity and allow the changes in each ecosystem to be characterised, evaluated and monitored (Karlen et al., 1997).

Agricultural land use causes changes in physical and chemical attributes of the soil. Which could lead to a decrease in quality as a result of the removal of plant cover and the excessive use of mechanisation or turning, among others. Due to the management practices employed, the productive capacity of the soil can be compromised under different agricultural systems (Rheinheimer et al., 2007).

Reis et al. (2021) attests that in an Ultisol with pasture and silvopasture area, there were changes in the chemical attributes of the soil and that when the system is well managed it is possible to maintain the quality of the soil. Chaves et. al (2021) in a study of changes in soil and clay fraction after cultivation with viticulture showed that there is change in chemical attributes, mineralogy and soil fertility over the years, especially where the soil is managed for a longer time with the input of chemical fertilizers. Santos et al. (2021), they concluded that soil management caused changes in soil structure and organic matter content, especially in the first $30 \mathrm{~cm}$, when subjected to tractor weight in the planting line. And changing the ground cover for planting vines leads to a reduction in carbon stock, compared to native pastures, for example. Rodrigues et al. (2017) evaluated changes in Amazonian soils under different uses and managements, with forest, native pasture, areas prepared by minimum tillage system and conventional tillage. They concluded that soil fertility was altered. Nutrient availability was reduced with the use of conventional tillage compared to the system with minimal soil disturbance.

From studies on soils with different uses, such as perennial crops, forestry and pasture that point to changes in soil quality, we hypothesize that these land uses have changed soil quality in this environment. The aims of this study were: to evaluate a series of physical and chemical attributes of soils under different types of land use and management, on the alluvial plain of the Arroio Dilúvio in Porto Alegre and to compare these types of land-use and management in relation to the amount of change caused in these attributes.

\section{Methodology}

The municipality of Porto Alegre has a great diversity of landscapes, due to variations in geology and geomorphology that are reflected in different soils (Hasenack et al., 2008). The Arroio Dilúvio (stream) cuts through almost the whole 
municipality, in an east-west direction, with an alluvial plain that has mostly been urbanised. Despite these changes caused by urbanization, this geomorphologic feature has great environmental importance in areas where natural landscape is maintained, like the presence of riparian forest, and others ecosystem functions. However, these lowlands are occupied by different types of land use at Agronomy Faculty of Rio Grande do Sul Federal University (FAGRO - UFRGS) campus, because of teaching, research and extension activities. Factors like the relief, and parent material of soils, make this environment representative of several areas in Porto Alegre municipality, that have been used in agricultural and non-agricultural activities.

The study was carried out in Porto Alegre, state of Rio Grande do Sul. Porto Alegre is inserted in the Pampa Biome, and is also influenced by the Atlantic Forest Biome. The climate in the region is classified as humid subtropical (EMBRAPA, 2014). Porto Alegre is located in the South Riograndense Shield, where the vast majority of the rocky substratum is occupied by granite rocks. Hills and mounds stand out in the landscape and there are also areas of flatlands composed of sediments of alluvial and colluvial origin (Hasenack, 2008).

Four landscape units (LU), also known as land-use types or treatments, were chosen for the study on the campus of the School of Agronomy at UFRGS, located on the alluvial plain of the Arroio Dilúvio. These comprise an area of Native Forest (NF), an area under an Agroforestry System (AFS), an area of Horse Farming (HF) and a demonstration area for Agricultural Crops (AC). The landscape units, or land-use types, are employed as an aid in teaching, research and extension activities, and each has a different history of land use and plant cover (Figure 1).

Figure 1 - Area of the FAGRO campus located on the plain of the Arroio Dilúvio, with emphasis on areas of interest to this study (Native forest; Agroforestry System; Horse Farm; Agricultural Crops).

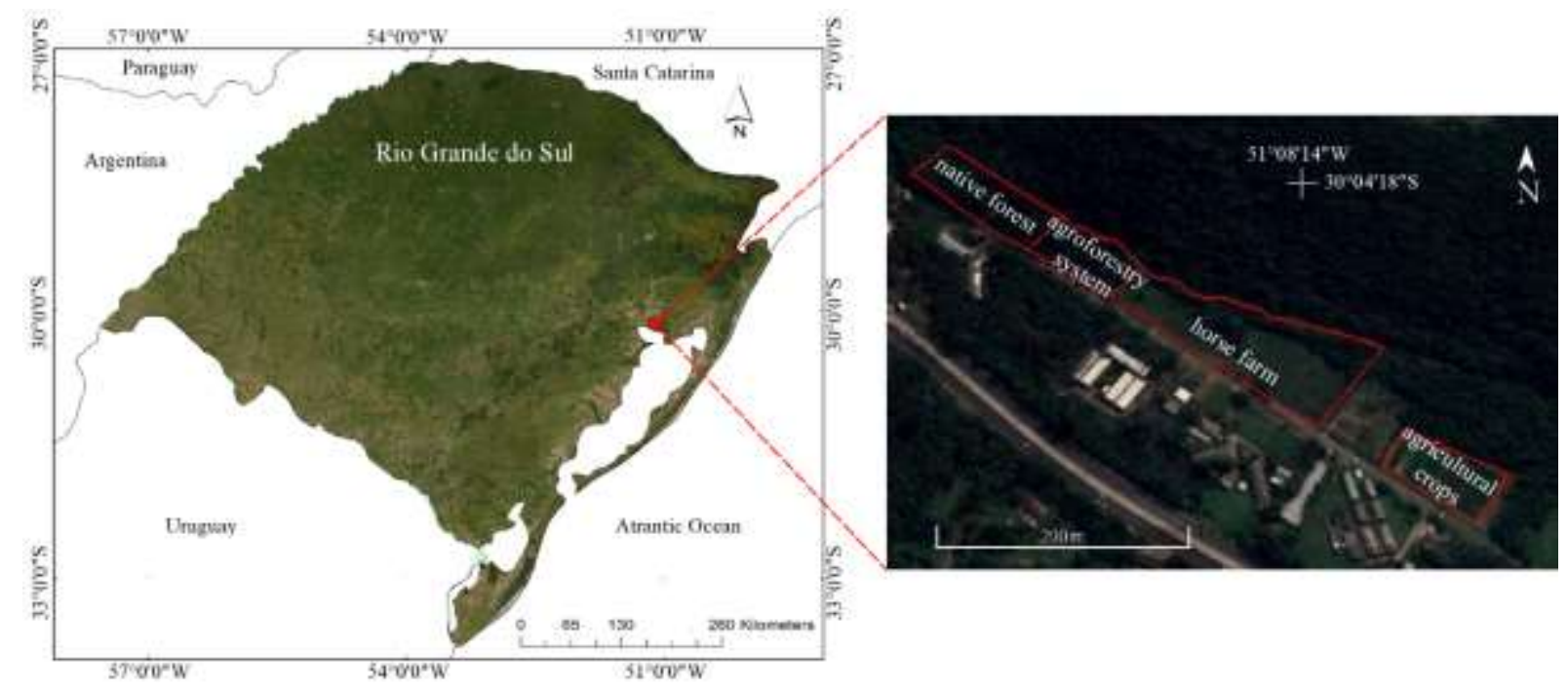

Source: Authors.

The NF is of flat relief, 30-40 years of age, occupied by recovered vegetation following deforestation, and maintained as a preservation area of soil and litter, without agricultural use and management. The AFS has flat relief and a system, introduced 10 years ago, of diverse vegetation with tree-like, shrubby and creeping species with the presence of plant ground cover, and is used for experimental agriculture. There were records of ground cover employing plant residue from pruning, and the use of cover crops and green manure (legumes and grasses), like common vetch (Vicia sp) and crotalaria (Crotalaria sp). The HF has flat relief, with a system of pasture planted 38 years ago, a vegetation of low grasses, with no fertiliser or liming. The AC landscape unit is of flat relief, used as a demonstration unit, including the cultivation of agricultural crops (oats, cassava, beans, maize, velvet beans, and soybeans), desiccated by the use of herbicides, with manual weeding, and is fallow or cultivated during the winter. Conventional soil tillage including ploughing and harrowing is employed, with exposure and 
turning of the surface soil. There are records that fertiliser and liming have not been used in this area in the last five years.

The soils of the Arroio Dilúvio alluvial plain have taxonomic classifications as "Cambissolo Flúvico" e "Gleissolo Háplico" (EMBRAPA, 2018) and all profiles are classified as "Gleyic Fluvic Cambisols" according to FAO (2015). In fact, the main difference between them is the depth of gleyic horizon, that occurs between 25 and $70 \mathrm{~cm}$.

The experimental design consisted of four replications per treatment or land use (LU). Undisturbed samples were collected from the surface layer using a steel cylinder $(10 \mathrm{~cm}$ in thickness), representing an approximate depth of 0 to $20 \mathrm{~cm}$. Disturbed soil samples were taken from the same points on and below the surface (at depths 0-20 and 60-80 cm respectively). The samples were air dried, grounded and sieved through $2 \mathrm{~mm}$ mesh. The undisturbed samples were saturated by capillary action for 48 hours, weighed and submitted to a tension equal to a $60 \mathrm{~cm}$ water column on a tension table for 72 hours. After balancing, the samples were drained and weighed. Finally, they were dried in an oven $\left(105^{\circ} \mathrm{C}\right)$ and again weighed, to calculate the volume of micropores, macropores and total pores, the latter by subtraction (EMBRAPA, 2011). Bulk density (BD) was calculated from the following formula: $\mathrm{BD}\left(\mathrm{g} \mathrm{cm}^{-3}\right)=$ Dry soil weight $(\mathrm{Wds}) /$ Total volume $(\mathrm{Vt})$. Particle size was determined using the pipette method, with prior separation of the sand by sifting, and the silt calculated by subtraction (EMBRAPA, 2011).

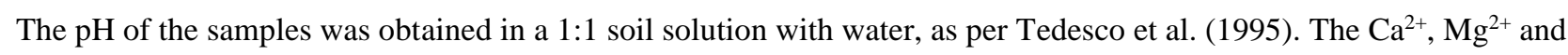
$\mathrm{Al}^{3+}$ content was obtained by atomic absorption spectrophotometry after extraction with $1.0 \mathrm{~mol} \mathrm{~L}^{-1} \mathrm{KCl}$. The potential acidity $(\mathrm{H}+\mathrm{Al}$ content) was estimated using the SMP method. The organic carbon content of the soil was obtained by organic-matter carbon oxidation, with potassium dichromate reduction in acid medium under high temperature. The $\mathrm{P}, \mathrm{K}$ and $\mathrm{Na}$ content was extracted by the Mehlich method (EMBRAPA, 2011), with P determined by colourimetry and K and Na by spectrophotometry (EMBRAPA, 2011). The $\mathrm{S}$ content was determined by colourimetry after extraction with $\mathrm{CaHPO}_{4}$ at $500 \mathrm{mg} \mathrm{L}^{-1} \mathrm{P}$. With the data from the analysis, it was possible to calculate the cation exchange capacity $\left(\mathrm{CEC}_{\mathrm{pH}} 7.0\right)$, sum of bases $(\mathrm{Sb})$ and base saturation $(\mathrm{V} \%)$.

The data were analysed using the SPSS v20.0 statistical package. The attributes were compared for land use by ANOVA at each depth, at $10 \%$ significance level. Data from some attributes required transformation (square root or logarithmic) because lack of homogeneity of variance. In some cases, non-parametric methods (the Kruskall-Wallis and MannWhitney tests) were applied. Additionally, a discriminant analysis was performed using principal discriminant functions and calculating the distances of each sample in relation to the centroid of the treatment for each depth sampled.

\section{Results and Discussion}

Clay content has a wide distribution, between 20 and 38 percent. Despite this, all samples could be included in classes 3 and 4, according Wietholther et al. (2004). This attribute wasn't analysed with respect to comparations between LUs, but is used to explanation of results involving other attributes, because clay contents are directly related to them. Bulk density can be used as a quality parameter that is related to soil compaction and to other attributes, such as porosity and soil moisture (Costa et al., 2007). This attribute showed significant statistical differences between the types of land use (treatments), with the highest density in $\mathrm{HF}$ of $1.90 \mathrm{~m}^{-3} \mathrm{~m}^{-3}$ (Table 1 ). 
Table 1 - Mean values and standard deviations of the physical attributes of soils under different types of land use and management, analysed at a depth of 0 to $20 \mathrm{~cm}$.

\begin{tabular}{|c|c|c|c|c|c|c|c|c|}
\hline \multirow[t]{2}{*}{ Land use } & \multicolumn{2}{|c|}{ Density } & \multicolumn{2}{|c|}{ Macroporosity } & \multicolumn{2}{|c|}{ Microporosity } & \multicolumn{2}{|c|}{ Total porosity } \\
\hline & $\mathrm{mn}$ & sd & $\mathrm{Mn}$ & sd & Mdn & $\mathrm{Sd}$ & $\mathrm{Mn}$ & Sd \\
\hline & \multicolumn{2}{|c|}{$\mathrm{g} / \mathrm{cm}^{3}$} & \multicolumn{6}{|c|}{ 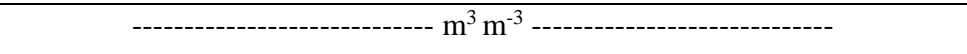 } \\
\hline Native Forest & $1.41 \mathrm{~B}$ & 0.13 & $0.08^{\mathrm{ns}}$ & 0.04 & $0.49^{\mathrm{ns}}$ & 0.08 & $0.57^{\mathrm{ns}}$ & 0.05 \\
\hline Agroforestry System & $1.53 \mathrm{~B}$ & 0.22 & 0.08 & 0.01 & 0.47 & 0.15 & 0.55 & 0.15 \\
\hline Horse Farm & $1.90 \mathrm{~A}$ & 0.14 & 0.07 & 0.42 & 0.41 & 0.04 & 0.48 & 0.06 \\
\hline Agricultural Crops & $1.71 \mathrm{AB}$ & 0.18 & 0.09 & 0.14 & 0.42 & 0.09 & 0.51 & 0.10 \\
\hline
\end{tabular}

$\mathrm{mn}=$ mean; $\mathrm{sd}=$ standard deviation. Uppercase letters indicate a significant difference at $10 \%$. ns = no significant difference. Source: Authors.

The critical density for root development is not the same for all soils, but some authors establish values of between 1.7 and $1.8 \mathrm{~g} \mathrm{~cm}^{-3}$ (Silva et al., 2015). The higher bulk density in HF is attributed to the compaction caused by the weight of the animals on the ground, and to the lack of management of the pastures in the area. This result is accompanied by lower values for macroporosity, microporosity and total porosity; however, these attributes, showed no significant differences between treatments. These results are in accordance with Vzzotto et al. (2000), where the study shows a reduction in total porosity and an increase in soil density, in the first five centimeters of depth of a flat soil. The study also shows that the roots of the pastures were not efficient in unpacking the soil in a period of six months after occupation of the area with cattle. Other studies also confirm the effect of animal trampling on soil compaction, such as Marchezan et al. (1998) who proved that there is an increase in soil density and a reduction in total porosity after a period of grazing on the soil. Considering the history of the HF, similar results were obtained by Correa \& Reichardt (1995), evaluating the influence of the time of 4, 6 and 10 years of grazing on physical characteristics of a soil, concluded that there was an increase in the resistance to penetration with over the years of grazing, in the $0-10 \mathrm{~cm}$ layer of soil.

The various land-use types under study showed significant differences in $\mathrm{pH}$ (Table 2). The highest value for $\mathrm{pH}$ at the surface was found in AFS (pH 5.3), showing no significant difference to HF.

The practice of incorporating pruning residue, together with the use of green manure, contributes to recycling and the increase of base cations in the soil. The lack of any difference with HF demonstrates the efficiency for nutrient cycling of the vegetation and animal waste. According to Vendramini et al. (2007) and Souza et al. (2018) animal waste deposited on pasture soil is the main source of nutrient return to the system. For this reason, there is a great importance of the manure to maintain soil fertility in the pasture, in which the animal excreta are responsible for the return of approximately 70 to $95 \%$ of the nutrients ingested by the animals, both in the form of urine and feces (Balbinot et al., 2009).

The lowest value for $\mathrm{pH}$ was found in NF ( $\mathrm{pH} 4.4$ ), with no significant difference to AC. The higher acidity found in the soil of NF, extremely acidic, can be explained by the existence of a large accumulation of plant residue, but only those with natural occurrence in the area, with a lack of turning of the surface soil creating an acidification front (Silva et al., 2015). 
Table 2 - Mean values for the chemical attributes of soils showing a significant difference between treatments (land use and management).

\begin{tabular}{|c|c|c|c|c|c|}
\hline Land use & pH & $\begin{array}{c}\mathbf{V} \% \\
\%\end{array}$ & $\begin{array}{c}\text { SOM } \\
\%\end{array}$ & $\begin{array}{c}\mathbf{C E} \\
\mathrm{cmol}_{\mathrm{c}} \mathrm{dm}^{-3}\end{array}$ & $\begin{array}{c}\text { Al } \\
\mathrm{cmol}_{\mathrm{c}} \mathrm{dm}^{-3}\end{array}$ \\
\hline & \multicolumn{5}{|c|}{$00-20 \mathrm{~cm}$ deep } \\
\hline Native Forest & $4.4 \mathrm{C}$ & $34.3 \mathrm{~B}$ & $2.88 \mathrm{~A}$ & $17.93 \mathrm{~A}$ & $0.70 \mathrm{AB}$ \\
\hline Agroforestry System & $5.3 \mathrm{~A}$ & $64.8 \mathrm{~A}$ & $1.78 \mathrm{~B}$ & $11.20 \mathrm{BC}$ & $0.10 \mathrm{~B}$ \\
\hline Horse Farm & $5.2 \mathrm{AB}$ & $61.5 \mathrm{AB}$ & $1.85 \mathrm{~B}$ & $12.85 \mathrm{~B}$ & $0.30 \mathrm{AB}$ \\
\hline \multirow[t]{2}{*}{ Agricultural Crops } & $4.6 \mathrm{BC}$ & $35.5 \mathrm{~B}$ & $1.15 \mathrm{~B}$ & $9.13 \mathrm{C}$ & $0.78 \mathrm{~A}$ \\
\hline & \multicolumn{5}{|c|}{$60-80 \mathrm{~cm}$ deep } \\
\hline Native Forest & $4.3 \mathrm{~B}$ & $16.3 \mathrm{~B}$ & $0.50^{\mathrm{ns}}$ & $14.10 \mathrm{~A}$ & $1.85 \mathrm{~A}$ \\
\hline Agroforestry System & $4.6 \mathrm{~A}$ & $31.5 \mathrm{AB}$ & 0.40 & $11.55 \mathrm{~A}$ & $1.65 \mathrm{AB}$ \\
\hline Horse Farm & $4.6 \mathrm{~A}$ & $36.5 \mathrm{AB}$ & 0.28 & $10.60 \mathrm{AB}$ & $1.83 \mathrm{~A}$ \\
\hline Agricultural Crops & $4.7 \mathrm{~A}$ & $42.2 \mathrm{~A}$ & 0.23 & $6.57 \mathrm{~B}$ & $0.55 \mathrm{~B}$ \\
\hline
\end{tabular}

V\%: base saturation; SOM: soil organic matter; CEC: cation exchange capacity; Al: Aluminium. Uppercase letters indicate significant differences between treatments within each depth. ns = no significant difference

Source: Authors.

The lowest value for $\mathrm{pH}$ in NF was repeated at a depth of $60-80 \mathrm{~cm}$, with no significant differences between the other types of land-use or management. AC was the only LU type where $\mathrm{pH}$ and base saturation increased with depth, with a significant difference at 60 to $80 \mathrm{~cm}$ in relation to all the other treatments. We evaluate that a little greater restriction on drainage in this LU appear to contribute to cation retention, resulting in a value for V\% significantly higher than in the other treatments.

Soil organic matter (SOM) is a good indicator of soil quality, since according to Mielnickzuk (1999), it is susceptible to changes due to management practices and may be related to most soil properties. At a depth of 0 to $20 \mathrm{~cm}$, NF presented the highest value for SOM (2.88\%), differing from the other treatments, with values ranging from $1.15 \%$ in $\mathrm{AC}$ to $1.85 \%$ in $\mathrm{HF}$. With exception of NF, all LU have SOM contents considered low (Wietholter et al., 2004). The greater value for SOM in NF shows that the use and management of the other soils under study reduced the $\mathrm{C}$ content of the soil, with a trend towards faster processes of mineralisation and lower input of organic materials in managed systems (Houghton et al., 1991). At a depth of 60$80 \mathrm{~cm}$, there were no significant differences between treatments, with measured values varying less than $0.5 \%$, which agrees with reports from other studies that the impact of land use and management occurs mostly in surface layer (Portugal et al., 2010).

The highest value for CEC was found in the soil of NF, with intermediate values in AFS and HF. AC had the lowest value for CEC. NF has a high value for CEC in $0-20 \mathrm{~cm}$; and all the others have medium values. The high CEC found in NF can be explained by the natural addition of plant residue to the system, with no rotation or exposure of the soil. For the study in question, CEC and SOM had a correlation coefficient of $\mathrm{r}=0.69(\mathrm{p}<0.05)$, at a depth of 0 to $20 \mathrm{~cm}$. SOM, with a large quantity of loadings in the functional groups, can contribute from $20 \%$ to $90 \%$ of soil CEC (Fontes et al., 2001). At depth (60$80 \mathrm{~cm}$ ), there were significant differences between land-use types, especially between NF and AC, establishing a significant correlation with clay $(\mathrm{r}=0.90, \mathrm{p}<0.05)$. As such, a change can be seen in the origin of the CEC dependent on land use and depth (Khaledian et al., 2017). 
AC presented the highest levels of soil Al at the surface, which can be explained by the low soil $\mathrm{pH}$. At this depth, the correlation coefficient between $\mathrm{pH}$ and exchangeable aluminium was $-0.90(\mathrm{p}<0.05)$, confirming the close relationship between the variables (Portugal et al., 2010). According to Silva et al. (2008), the organic acids present in the SOM can reduce Al toxicity, since they participate in the complexation process, changing the mobility and solubility. At a depth of 60 to $80 \mathrm{~cm}$, the area of AC stands out with the lowest values for Al. In this case, the influence of the water regime is evaluated, the water remaining longer in the soil, increasing the $\mathrm{pH}$ (Minasny et al., 2016). The $\mathrm{pH}$ to $\mathrm{Al}$ ratio had a coefficient of -0.71 ( $\mathrm{p}<0.05$ ), while clay and $\mathrm{Al}$ had a correlation coefficient of $\mathrm{r}=0.61$, also significant at $5 \%$.

The phosphorus content showed no significant differences between treatments in both depths, despite the values having presented marked differences at the surface, similar to NF and HF (Table 3).

Table 3 - Mean values and standard deviations of the chemical attributes, phosphorus and sulphur under different types of land use and management.

\begin{tabular}{|c|c|c|c|c|}
\hline \multirow[t]{2}{*}{ Land use } & \multicolumn{2}{|c|}{ Phosphorus } & \multicolumn{2}{|c|}{ Sulphur } \\
\hline & \multicolumn{2}{|c|}{$\mathrm{mg} \mathrm{kg}^{-1}$} & \multicolumn{2}{|c|}{$\mathrm{mg} \mathrm{kg}^{-1}$} \\
\hline & \multicolumn{4}{|c|}{ 00-20 cm deep } \\
\hline Native Forest & $32.7^{\mathrm{ns}}$ & 22.7 & $30.3 \mathrm{~A}$ & 10.8 \\
\hline Agroforestry System & 23.2 & 15.00 & $14.0 \mathrm{~B}$ & 2.8 \\
\hline Horse Farm & 17.1 & 19.1 & $17.3 \mathrm{~B}$ & 7.9 \\
\hline \multirow[t]{2}{*}{ Agricultural Crops } & 18.5 & 13.9 & $18.0 \mathrm{AB}$ & 1.8 \\
\hline & \multicolumn{4}{|c|}{$00-60 \mathrm{~cm}$ deep } \\
\hline Native Forest & $5.6^{\mathrm{ns}}$ & 02.0 & $33.5^{\mathrm{ns}}$ & 5.5 \\
\hline Agroforestry System & 3.5 & 0.8 & 29.0 & 16.7 \\
\hline Horse Farm & 4.6 & 0.9 & 25.5 & 14.5 \\
\hline Agricultural Crops & 5.1 & 01.3 & 16.7 & 8.5 \\
\hline
\end{tabular}

ns $=$ no significant difference. Source: Authors.

Great variability in the LUs, expressed by high standard deviation values, resulted in absence of sensible diferences between them. The fact that there are no treatments with intensive applications of phosphorus also contributes to this lack of difference, but is importante to note that, mainly in NF, phosphorus content is generally high. According to Selle (2007), plant residues from the forest are the main means of transferring carbon, nitrogen and phosphorus to the soil and the greatest contribution to nutrient cycling is offered by the leaves, being responsible for about 67.5 to $75 \%$ of total nutrients transferred.

This trend in distribution was repeated for sulphur, but with significant differences for NF in relation to HF and AFS in layer $0-20 \mathrm{~cm}$, once again demonstrating the importance of native forest in cycling and maintaining sulphur in the surface layers (Toledo et al., 2002; Cunha et al., 2013). At a depth of 60 to $80 \mathrm{~cm}$, no difference was detected between land-use type, the greater values at depth being highlighted due to the dynamics of the element itself (Rheinheimer et al., 2007). The elements $\mathrm{Cu}$ and $\mathrm{Zn}$ showed significant differences only for $\mathrm{Cu}$ at a depth of 0 to $20 \mathrm{~cm}$ (not shown). AFS had significantly higher values than AC and NF, and although it wasn't stated in the interviews, we evaluate that some composts used in diseases treatments had an important influence (Brunetto et al., 2018).

The samples were analysed relative to a set of determined attributes, to compare their attributes in relation to the mean values for each land-use type. Discriminant functions within the multivariate analysis were used for this, with attributes that presented a significant difference between treatments. Thus, for both depths, $\mathrm{pH}, \mathrm{CEC}$, and the levels of clay, organic matter, phosphorus and sulphur were used. Soil density was used in 0-20 $\mathrm{cm}$ depth.

At 0 to $20 \mathrm{~cm}$, the two principal discriminant functions expressed approximately $92 \%$ of the variation, with function 1 showing a greater relationship to CEC and organic matter, while function 2 was mainly related to $\mathrm{pH}$ and sulphur (Figure 2). 
Figure 2 - Values assumed by centroids for the land-use types and samples under analysis from discriminant functions, at a depth of 0 to $20 \mathrm{~cm}$. 1 - Agricultural crops (AC); 2 - Agroforestry System (AFS); 3 - Horse Farm (HF); 4 - Native Forest (NF).

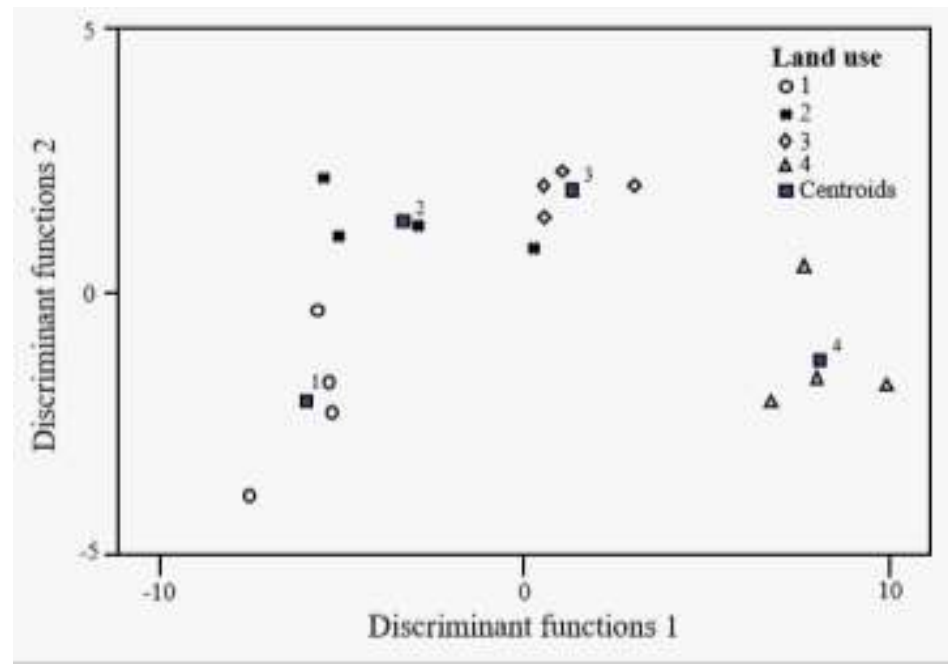

Source: Authors.

Each of the 16 samples was classified as to treatment or original land-use type, with no sample being reclassified; NF presented greater differentiation between the types of land use, while HF and AFS showed the smallest distance between each other, followed by AFS and AC. It can be seen from the position of the representative centroids for land-use type, that the intensity of the land use and management was a defining factor in the behaviour of the treatments, with more intensive uses gradually assuming lower values for function 1 (Benites et al. 2010). Consolidation of these different land-use types of marked installation time and with very clear differences between management practices, resulted in well-defined behaviour for the types of land use and management under analysis. Whereas, at 60 to $80 \mathrm{~cm}$, two groups were clearly formed, AFS and NF, and $\mathrm{HF}$ and AC respectively (Figure 3).

Figure 3 - Values assumed by centroids for the land-use types and samples under analysis from discriminant functions, at a depth of 60 to $80 \mathrm{~cm}$. 1 - Agricultural crops (AC); 2 - Agroforestry System (AFS); 3 - Horse Farm (HF); 4 - Native Forest (NF).

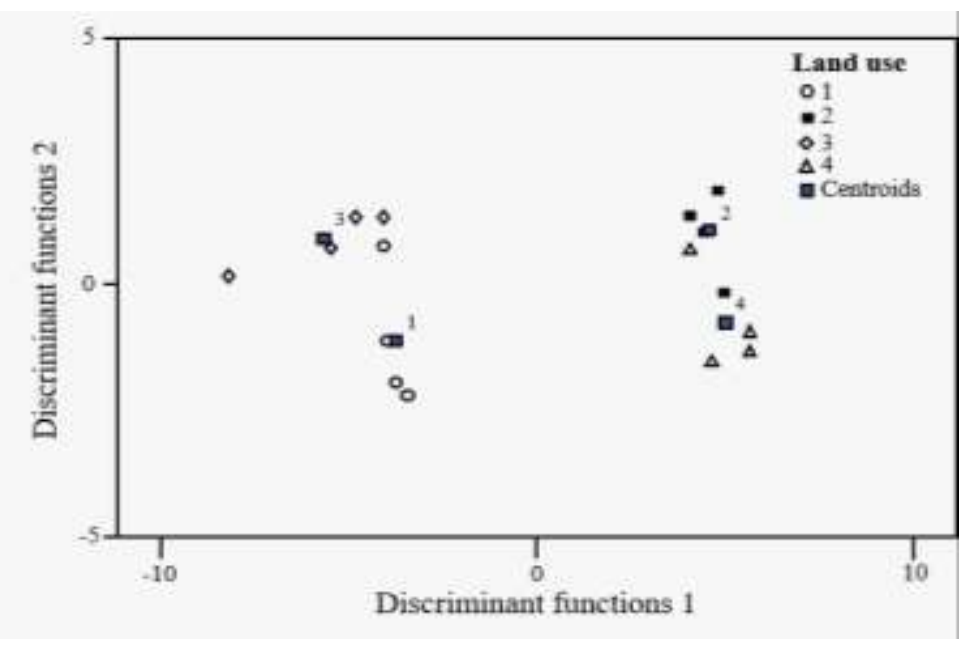

Source: Authors. 
In this case, there seems to be an influence from the spatial positioning of the area of each treatment, which is reinforced by the fact that a sample of NF was reclassified as an area of AFS, which in turn had a sample reclassified as NF; one sample of AC was reclassified as HF. In this way, thirteen samples had their initial classifications confirmed. These results, examined from a pedologic perspective, suggests that this soil, formed from alluvial deposits, may have some variations in depth and thickness of the deposition layers. These are expressed in the areas of the treatments showing the greatest distance between each other (Santos et al., 2012). So, it was possible conclude that, in surficial layer, land use and management intensities was the main factor responsible for similarities and differences between LUs. For example, the more likelihood occurred between AFS and HF may be interpreted like a result related with relatively similar degree of intensity and environmental impact. On the other hand, at 60 to $80 \mathrm{~cm}$. depth, physical proximity seems to be the main factor, grouping $\mathrm{HF}$ and $\mathrm{AC}$, and NF and AFS.

\section{Conclusion}

Changes were detected in chemical and physical attributes of the soils under the different types of land-use and management. Among the physical attributes, only bulk density showed significant differences between treatments.

Chemical soil indicators displayed significant differences, such as $\mathrm{pH}$, base saturation (V\%), SOM, CEC, and Al, with NF having the lowest values for $\mathrm{pH}$ at the surface, and the highest for CEC and SOM, consistent with an unused landscape unit and agriculture use.

There appears to be different causes for the behaviour of each land-use type according to depth. At the surface, the treatment with the lowest use intensity (NF) showed greater differentiation compared to the other treatments, whereas HF assumed intermediate values between this and the other treatments (AFS and AC). At this depth, the influence of land-use type and management was more marked. At 60 to $80 \mathrm{~cm}$, the greatest cause of the differences was spatial distance, emphasising the spatial variability of these soils.

Finally, some attributes indicated processes of alteration that are reflected in soil degradation, at least in its initial stages. This is the case of HF, with high bulk density, and AC, with low levels of organic matter, together with the extremely acidic $\mathrm{pH}$ and higher aluminum content. These results highlight the susceptibility to impacts generated from land uses and management changes, and the importance of sustainable use in this environment.

To complement this research, new studies with other chemical and physical attributes of these soils, in the four Landscape Units, are important. Thus, it will be possible to obtain new indices and soil quality parameters.

With the maintenance and preservation of these Landscape Units, it will be possible to generate data on changes due to use and long-term management in this plain, creating important reference data.

\section{Acknowledgments}

The authors would like to thank the Conselho Nacional de Desenvolvimento Científico e Tecnológico (CNPq) for the Master's scholarship. The authors further wish to thank the departments of Agriculture, Zootechnics and Plant Health of the School of Agronomy at UFRGS. Thanks are also due to the UVAIA group and to the administration of the School of Agronomy at UFRGS.

\section{References}

Araújo, E. A., Ker, J. C., Neves, J. C. L. \& Lani, J. L. (2012). Qualidade do solo: conceitos, indicadores e avaliação. Revista Brasileira de Tecnologia Aplicada nas Ciências Agrárias, 5(1), 187-206. 10.5777/PAeT.V5.N1.12

Balbinot Junior, A. A., Moraes, A. de, Veiga, M. da, Pelissari, A \& Dieckow, J. (2009). Integração lavoura-pecuária: intensificação de uso de áreas agrícolas. Ciência Rural, 39(6), 1925-1933. https://doi.org/10.1590/S0103-84782009005000107 
Benites, V. M., Moutta, R. O., Coutinho, H. L. C. \& Balieiro, F. C. (2010). Análise discriminante de solos sob diferentes usos em área de mata Atlântica a partir de atributos de matéria orgânica. Revista Árvore, 34(4), 685-900. https://doi.org/10.1590/S0100-67622010000400013

Bruneto, G., Comin, J. J., Miotto, A., Moraes, M. P. de, Sete, P. B., Schimitt, D. E., Gatiboni, L. C., Mello, G. W. B. de \& Morais, G. P. (2018). Copper and zinc accumulation, fractionation and migration in vineyard soils from Santa Catarina State, Brazil. Bragantia, 77(1), 141-151. https://doi.org/10.1590/16784499.2016391

Chaves, E., Santos, C. V. dos, Ramos, P. V., Inda Junior, A. V. \& Caner, L. (2021). Propriedades físicas de um Argissolo após 17 anos de florestamento com Eucalyptus spp. Research, Society and Development, 10(5), e58610514424. http://dx.doi.org/10.33448/rsd-v10i5.14424

Correa, J. C. \& Reichardt, K. (1995). Efeito do tempo de uso das pastagens sobre as propriedades de um latossolo amarelo da Amazônia Central. Pesquisa Agropecuária Brasileira, 30(1): 107-114.

Costa, M. J., Rosa Junior, E. J., Rosa, Y. B. C. J., Souza, L. C. F. de \& Rosa, C. B. J. (2007). Atributos químicos e físicos de um latossolo sendo influenciados pelo manejo do solo e efeito da gessagem. Acta Scientiarum.Agronomy, 29(5), 701-708. https://doi.org/10.4025/actasciagron.v29i5.751

Cunha, F. V., Leles, P. S. S., Pereira, M. G., Bellumath, V. G. H. \& Alonso, J. M. (2013). Acúmulo e decomposição da serapilheira em quatro formações florestais. Ciência Florestal, 23(3), 379-387. https://doi.org/10.5902/1980509810549

Embrapa - Empresa Brasileira de Pesquisa Agropecuária. (2011). Manual de métodos de análies de solo. EMBRAPA Solos.

Embrapa - Empresa Brasileira de Pesquisa Agropecuária. (2014). Banco de Dados Climáticos do Brasil: município: Porto Alegre- RS. [Base de Dados]. https://www.cnpm.embrapa.br/projetos/bdclima/balanco/resultados/rs/225/balanco.html

Embrapa - Empresa Brasileira de Pesquisa Agropecuária. (2018). Sistema Brasileiro de Classificação de Solos. (5a ed.), EMBRAPA.

FAO - Food and Agriculture Organizations of United Nations. (2015). World reference base of soil resources. https://www.fao.org/3/i3794en/I3794en.pdf

Fontes, M. P. F., Camargo, O. A. de \& Sposito, G. (2001). Eletroquímica das partículas coloidais e sua relação com a mineralogia de solos altamente intemperizados. Scientia Agricola, 58(3), 627-646. https://doi.org/10.1590/S0103-90162001000300029

Hasenack. H. (2008). Diagnóstico Ambiental de Porto Alegre: Geologia, Solos, Drenagem, Vegetação/Ocupação e Paisagem. http://www.ecologia.ufrgs.br/labgeo/arquivos/Publicacoes/Livros_ou_capitulos/2008/Hasenack_et_al_2008_Diagnostico_ambiental_de_Porto_Alegre.pdf

Houghton, R. A., Lefkowitz, D. S. \& Skole, D. L. (1991). Changes in the landscape of Latin American between 1850 and 1985. Net release of CO2 to the atmosphere. Forest Ecology and Management, 38(3-4), 173-199. https://doi.org/10.1016/0378-1127(91)90140-Q

Karlen, D. L., Mausbach, M. J., Doran, J. W., Cline, R. G., Harris, R. F. \& Schuman, G. E. (1997). Soil quality: a concept, definition and framework for evaluation. Soil Science Society America Journal, 61, 4-10.

Khaledian, Y., Brevik, E. C., Pereira, P., Cerdà, A., Fattah, M. A. \& Tazikeh, H. (2017). Modeling soil cation exchange capacity in multiple countries. Catena, 158, 194-200. https://doi.org/10.1016/j.catena.2017.07.002

Marchezan, E., Vizzotto, V. R. \& Zimmermann, F. L. (1998). Produção de forrageiras de inverno em diferentes espaçamentos entre drenos superficiais sob pastejo animal em várzea. Ciência Rural, 28(3), 393-397. https://doi.org/10.1590/S0103-84781998000300007

Mielniczuck, J. (1999). Matéria orgânica e a sustentabilidade de sistemas agrícolas. Gênesis.

Minasny, B., Hong, S. Y., Hartemink, A. E., Kim, Y. H. \& Kang, S. S. (2016) Soil pH increase under paddy in South Korea between 2000 e 2012. Agriculture, Ecosystem and Environment, 221, 205-213. https://doi.org/10.1016/j.agee.2016.01.042

Portugal, A. F., Costa, O. D. V. \& Costa, L. M. da. (2010). Propriedades físicas e químicas do solo em áreas com sistemas produtivos e mata na região da Zona da Mata mineira. Revista Brasileira de Ciência do Solo, 34(2), 575-585.

Reis, A. S., Leite, R. C., Soares, G. O. S., Soares, J. L. S., Gonçalves, F. B., Fidelis, R. R. \& Santos, A. C. dos. (2021). Soil Chemical attributes under different management systems in Cerrado-Amazon ecotone. Research, Society and Development, 10(7), e36210716045. https://doi.org/10.33448/rsd-v10i7.16045

Rheinheimer, D. dos S., Rasche, J. W. A., Osorio Filho, B. D. \& Silva, L. S. da. (2007). Resposta a aplicação e recuperação de enxofre em cultivos de casa de vegetação em solos com diferentes teores de argila e matéria orgânica. Ciência Rural, 37(2), 363-371. https://doi.org/10.1590/S0103-84782007000200011

Rodrigues, M., Rabêlo, F. H. S., Castro, H. A., Roboredo, D., Carvalho, M. A. C. de \& Roque, C. G. (2017). Changes in Chemical properties by use and management of na oxisol in the Amazon Biome. Revista Caatinga, 30(2), 278-286. https://doi.org/10.1590/1983-21252017v30n202rc

Santos, C. V, Levien, R., Mazzurana, M. \& Zulpo, L. (2021). Organic carbon dynamics in interrows of Vitis vinifera with different years of soil use and management. Research, Society and Development, 10(3), e10610311840. https://doi.org/10.33448/rsd-v10i3.11840

Santos, K. S., Montenegro, A. A. A., Almeida, B. G. de, Montenegro, S. M. G. L., Andrade, T. da S. \& Fontes Júnior, R. V. de P. (2012). Variabilidade espacial de atributos físicos em solos de vale aluvial no semiárido de Pernambuco. Revista Brasileira de Engenharia Agrícola e Ambiental, 16(8), 828-835. https://doi.org/10.1590/S1415-43662012000800003

Selle, GL. (2007). Ciclagem de nutrients em ecossistemas florestais. Bioscence, 23 $29-39$. http://www.seer.ufu.br/index.php/biosciencejournal/article/view/6912

Silva, G. F. da, Santos, D., Silva, A. P. da \& Souza, J. M. de. (2015). Indicadores de qualidade do solo sob diferentes sistemas de uso na mesorregião do agreste pernambucano. Revista Caatinga, 28(3), 25- 35. https://doi.org/10.1590/1983-21252015v28n303rc 
Research, Society and Development, v. 10, n. 16, e78101623317, 2021

(CC BY 4.0) | ISSN 2525-3409 | DOI: http://dx.doi.org/10.33448/rsd-v10i16.23317

Silva, L. B., Dick, D. P. \& Inda Junior, A. V. (2008). Solos subtropicais de altitude: Atributos químicos, teor de matéria orgânica e sua resistência à oxidação química. Ciência Rural, 38(4), 1167-1171. https://doi.org/10.1590/S0103-84782008000400044

Souza, M. de S., Jardim, A. M. da R. F., Araújo Júnior, N., Silva, J. R. I., Leite, M. L. de M. V., Teixeira, V. I. \& Silva, T. G. F da. (2018). Ciclagem de nutrientes em ecossistemas de pastagens tropicais. PubVet, 12(5), 1-9. https://doi.org/10.22256/pubvet.v12n5a91.1-9

Tedesco, M. J. (1995). Análises de solo, plantas e outros materiais. (2a ed.), Departamento de Solos UFRGS.

Toledo, L. O., Pereira, M. G. \& Menezes, C. E. G. (2002). Produção de Serapilheira e transferência de nutrientes em florestas secundárias localizadas na região de Pinheiral, RJ. Ciência Florestal, 12(2): 9-16. https://doi.org/10.5902/198050981676

Vendramini, J. M. B., Silveira, M. L. A., Dubeux Jr., J. C. B. \& Sollenberger, L. E. (2007). Environmental impacts and nutrient recycling on pastures grazed by cattle. Revista Brasileira de Zootecnia, 36, 139-149. https://doi.org/10.1590/S1516-35982007001000015

Vzzotto, V. R., Marchezan, E. \& Segabinazzi, T. (2000). Efeito do pisoteio bovino em algumas propriedades físicas do solo de várzea. Ciência Rural, 30(6), 965-969.

Wiethölter, S. (2004). Manual de adubação e calagem para os estados do Rio Grande do Sul e Santa Catarina. 10 ed. Sociedade Brasileira de Ciência do Solo. Núcleo Regional Sul. 